\title{
УЧЕБНЫЙ ПРЕДМЕТ ОРКСЭ КАК ОДИН ИЗ СПОСОБОВ ПАТРИОТИЧЕСКОГО ВОСПИТАНИЯ ШКОЛЬНИКОВ
}

\author{
Клишина Марина Сергеевна \\ МОУ Дашковская СОШ
}

Аннотация: Данное мероприятие состоит из презентации по патриотической тематике, в ходе которой учащиеся разбирают понятия патриотизма, родины, знакомятся с символикой государства, с понятиями народной символики страны.

В ходе данного мероприятия использованы следующие методы и формы работы:

- словесные (решают задачу формирования теоретических и фактических знаний и способствуют развитию логического мышления, речевых умений и эмоциональной сферы личности);

- наглядные (решают задачи развития образного мышления, познавательного интереса, воспитания художественного вкуса, способствуют формированию культурной эрудиции);

Ученики отвечают на вопросы по тематике и ставят новые как перед собой, так и перед учителем, что способствует дальнейшему развитию личностного роста и воспитанию в детях понятий, связанных с патриотизмом: родина, любовь к родине, малая родина, символика государства и т.д.

Ключевые слова: Патриотизм, символика, национальное самосознание.

\section{THE EDUCATIONAL SUBJECT OF THE ORCSE AS ONE OF THE WAYS OF PATRIOTIC EDUCATION OF SCHOOLCHILDREN}

\section{Klishina Marina Sergeevna}

\begin{abstract}
This event consists of a presentation on patriotic topics, during which students understand the concept of patriotism, the Motherland, get acquainted with the symbols of the state, with the concepts of national symbols of the country.

During this event, the following methods and forms of work were used:
\end{abstract}


- verbal (solve the problem of forming theoretical and factual knowledge and contribute to the development of logical thinking, speech skills and the emotional sphere of the individual);

- visual (solve the problems of developing imaginative thinking, cognitive interest, education of artistic taste, contribute to the formation of cultural erudition);

They answer questions on the subject and pose new ones, both to themselves and to the teacher, which contributes to the further development of personal growth and education in children of concepts related to patriotism - Motherland, love for the Motherland, definitions of a small Homeland, symbols of the state, etc.

Key words: Patriotism, symbolism, national identity.

При подготовке к данному выступлению нами было найдено 13 разных определений слова патриотизм в различных словарях. Мы сделали выбор в пользу определения из словаря-справочника по культурологии. Патриотизм нравственный принцип, нравственная норма и нравственное чувство, возникшие еще на заре становления человечества и глубоко осмысленные уже античными теоретиками. Патриот - человек, выражающий и реализующий в своих поступках глубокое чувство уважения и любви к родной стране, ее истории, культурным традициям, ее народу. Как стойкое нравственное чувство патриотизм вырастает из особенностей образа жизни и культурных традиций того или иного этноса, формируется в процессе овладения подрастающими поколениями языком и господствующими формами мышления, нормами и эталонами культуры и закрепляется в определенных фиксированных установках поведения благодаря общению с представителями старших поколений, одобряющих или порицающих поведение молодых. Нам кажется, что оно наиболее емко отражает цели и задачи патриотического воспитания школьников.

Очень важной задачей для государства и общества во все времена было формирование национального самосознания, гражданственности, патриотизма, духовно-нравственных ценностей. Сейчас российская государственность укрепляется через приобщение к изучению исторического, культурного и духовно-нравственного наследия отечества.

В 2019 году утверждаются новые федеральные государственные образовательные стандарты (ФГОС). И в общих положениях мы читаем, что стандарт направлен на формирование у обучающихся системных знаний о месте России в мире, ее исторической роли, территориальной целостности, 
культурном и технологическом развитии, вкладе в мировое научное наследие и на этой основе на формирование представлений о современной России, устремленной в будущее. В учебный план нового ФГОС входят обязательные предметные области (учебные предметы), одной из которых являются основы религиозных культур и светской этики (основы православной культуры, основы иудейской культуры, основы буддийской культуры, основы исламской культуры, основы мировых религиозных культур, основы светской этики).

B IV разделе документа прописаны требования к результатам освоения основной образовательной программы начального общего образования. Стандарт устанавливает требования к результатам обучающихся, освоивших основную образовательную программу начального общего образования: личностным, метапредметным и предметным. Их очень много, мы перечислим те, которые непосредственно касаются темы доклада.

Личностные результаты освоения основной образовательной программы начального общего образования должны отражать сформированность у обучающихся (в соответствии с направлениями воспитания):

1) ценностного отношения к своей родине - России;

2) понимания своей этнокультурной и российской идентичности, сопричастности к настоящему и будущему своей страны и родного края;

3) уважения к другим народам (патриотическое воспитание).

Мы понимаем, что эти результаты учитель может и должен формировать на каждом уроке. На уроках русского языка и чтения, даже на уроках математики. Но, конечно, в начальной школе есть два предмета, на которых личностные и предметные результаты, связанные с гражданским и патриотическим воспитанием, формируются на каждом занятии. Это предмет «ОРКСЭ».

В стандартах прописаны требования к предметным результатам освоения основной образовательной программы начального общего образования. Предметные результаты освоения основной образовательной программы начального общего образования с учетом специфики содержания предметных областей, включающих в себя конкретные учебные предметы, ориентированы на применение знаний, умений и навыков обучающимися в учебных ситуациях и реальных жизненных условиях и должны обеспечивать следующее. 
Основы религиозных культур и светской этики:

1) понимание необходимости нравственного совершенствования, духовного развития, роли в этом личных усилий человека;

2) формирование умений анализировать и давать нравственную оценку поступкам, отвечать за них, проявлять готовность к сознательному самоограничению в поведении;

3) осуществление обоснованного нравственного выбора с опорой на этические нормы религиозных культур (религиозной культуры);

4) формирование умений рассказывать об основных особенностях вероучений (вероучения) традиционных религий (традиционной религии) России, называть имена (имя) их (ее) основателей (основателя) и основные события, связанные с историей их (ее) возникновения и развития;

5) знание названий священных книг традиционных религий (традиционной религии) России, умение кратко описывать их содержание;

По выбору родителей (законных представителей) изучаются основы православной культуры, основы иудейской культуры, основы буддийской культуры, основы исламской культуры, основы мировых религиозных культур, основы светской этики.

6) формирование умений называть и составлять краткие описания особенностей культовых сооружений, религиозных служб, обрядов и таинств традиционных религий (традиционной религии) России;

7) построение суждений оценочного характера, раскрывающих значение нравственности, веры как регуляторов поведения человека в обществе и условий духовно-нравственного развития личности;

8) понимание ценности семьи, умение приводить примеры положительного влияния религиозных традиций (религиозной традиции) на отношения в семье, воспитание детей

9) овладение навыками общения с людьми разного вероисповедания;

10) осознание, что оскорбление представителей другой веры есть нарушение нравственных норм поведения в обществе;

11) понимание ценности человеческой жизни, человеческого достоинства, честного труда людей на благо человека, общества;

12) формирование умений объяснять значение слов «милосердие», «сострадание», «прощение», «дружелюбие»; 
13) умение находить образы, приводить примеры проявлений любви к ближнему, милосердия и сострадания в религиозных культурах (религиозной культуре), истории России, современной жизни;

14) открытость к сотрудничеству, готовность оказывать помощь; осуждение любых случаев унижения человеческого

Основы светской этики:

1) формирование умения строить суждения оценочного характера о роли личных усилий для нравственного развития человека;

2) формирование умения анализировать и давать нравственную оценку поступкам, отвечать за них, проявлять готовность к сознательному самоограничению в поведении;

3) способность осуществлять и обосновывать нравственный выбор, опираясь на принятые в обществе нормы морали и внутреннюю установку личности поступать согласно своей совести;

4) знание общепринятых в российском обществе норм морали, отношений и поведения людей, основанных на российских традиционных духовных ценностях, конституционных правах, свободах и обязанностях гражданина;

5) формирование умения соотносить поведение и поступки человека с основными нормами российской (гражданской) светской этики;

6) формирование умения строить суждения оценочного характера о значении нравственности в жизни человека, коллектива, семьи, общества;

7) знание и готовность ориентироваться на российские традиционные семейные ценности, нравственные нормы поведения в коллективе, обществе, соблюдать правила этикета;

8) понимание ценности человеческой жизни, человеческого достоинства, честного труда людей на благо человека, общества;

9) формирование умения объяснять значение слов «милосердие», «сострадание», «прощение», «дружелюбие»;

10) формирование умения приводить примеры проявлений любви к ближнему, милосердия и сострадания в истории России, современной жизни;

11) готовность проявлять открытость к сотрудничеству, готовность оказывать помощь; осуждать любые случаи унижения человеческого достоинства.

В контексте учебного курса ОРКСЭ культура понимается как образ жизни, обычаи, традиции и верования, духовное и материальное богатство 
народов мира. Духовно-нравственное воспитание младшего школьника рассматривается как формирование и развитие ценностного отношения к людям, обществу, природе, Родине, к своему и другим народам, их истории, культуре, духовным традициям

Одна из воспитательных целей курса это - гражданственность как чувство родины, неразрывной связи с Отечеством, причастности к его судьбе. Итак, мы видим, что одна из приоритетных задач школы - воспитать будущее поколение россиян, которое сможет обеспечить устойчивость, консолидацию, целостность нашего общества и государства. Для этого необходимо воспитывать патриотизм, любовь и уважение к нашей Родине - России, к своей малой Родине, к своей семье, готовить юных граждан к службе в армии, к выполнению священного долга по защите Отечества. Этим проблемам в модуле Основы светской этики посвящены темы занятий: «Россия - наша Родина», «Честь и достоинство», «Род и семья - исток нравственных отношений», «Нравственные идеалы», «Жизнь человека - высшая нравственная ценность», «Любовь и уважение к Отечеству». На подобных уроках учащиеся узнают о традициях дружной семьи народов России, о семейных традициях, о Вооруженных силах РФ, об истории ратных подвигов наших предков и героях современности.

В модуле «Основы православной культуры» эти вопросы раскрываются на темах, непосредственно связанных с семейными ценностями, которые закладывают основу для формирования нравственных идеалов, принятых в обществе, чувство гордости за свою Родину, свой народ. Это уроки; «Россиянаша родина», «Христианская семья», «Защита Отечества», «Подвиг», «Любовь и уважение к отечеству». При изучении этих тем продолжается формирование гражданских качеств личности младшего подростка, происходит усвоение положительного опыта, накопленного предыдущими поколениями. У детей формируется чувство гордости за свою Родину и свой народ. Учащиеся раскрывают содержание понятия - патриотизм, как чувство любви человека к своему Отечеству, нации, преданность стране, в которой живешь, в чем он проявляется, можно ли ему научиться. При изучении понятия «патриот», учащиеся узнают, что «патриот» - это не только человек, любящий свою Родину, но и готовый ради нее на ратные и трудовые подвиги.

На всех этих уроках мы можем и должны освещать и осмысливать подвиг нашего народа в годы Великой отечественной войны. Героические страницы Великой Отечественной войны обладают большой притягательной 
силой. Подвиги наших соотечественников, их доблестный труд в тылу широко отражены в художественной литературе, кинофильмах, живописи, музыке, скульптуре. Использование этого материала на уроках помогает усилению познавательного интереса, способствует эмоциональной вовлеченности, сопереживания, приобщению к изучению исторического наследия России. Этому также способствует применение в процессе преподавания курса ОРКСЭ активных форм работы приемов и методов обучения. Главное, чтобы они формировали умения принимать решения и решать проблемы, формировали коммуникативные умения и качества, умения ясно формулировать мысли, выслушивать и принимать во внимание разные точки зрения и мнения других людей, лидерские умения и качества, умение работать в команде.

В своей работе мы практикуем разные методы и формы работы:

- словесные (решают задачу формирования теоретических и фактических знаний и способствуют развитию логического мышления, речевых умений и эмоциональной сферы личности);

- наглядные (решают задачи развития образного мышления, познавательного интереса, воспитания художественного вкуса, способствуют формированию культурной эрудиции);

- практические, проблемно-поисковые и методов самостоятельной работы (необходимы для закрепления теоретических знаний и способствуют совершенствованию умений практической деятельности в конкретной сфере, развитию самостоятельности мышления и познавательного интереса);

- репродуктивные (необходимы для освоения фактических знаний, развития памяти, совершенствования навыков учебного труда)

- эвристические беседы:

- диспуты;

- учебные и социальные проекты;

- уроки - экскурсии;

- деловые и ролевые игры;

- драматизация (театрализация);

- практикумы;

- викторины и конкурсы;

- творческие мастерские;

- интервью; 
- сочинение, эссе;

- составление словаря терминов и понятий;

- создание галереи образов и т. д

Таким образом, именно на уроках ОРКСЭ можно создать атмосферу непосредственную, живую, с искренней заинтересованностью детей в материале урока. Дети всегда ждут этот предмет. У них возникает множество вопросов, которые они не могут обсудить с родителями, не находят ответы в современном мире. Иногда кажется, что нынешних детей интересуют только гаджеты и то, что с ними связано, однако на уроках ОРКСЭ раскрывается их жажда знания о мире, о человеческих отношениях, о понятии добра и зла, о моральной стороне поступков. Поэтому задачей учителя является использование этого потенциала в формировании их мировоззрения и воспитания гражданственности и патриотизма, любви к своей Родине, к своему народу, к своим корням, понимания того, что не хлебом единым жив человек, что душа человека ищет пищи духовной. Своё выступление мы хотим закончить словами святого праведного Иоанна Кронштадтского: «Помните, что Отечество земное с его Церковью есть преддверие Отечества Небесного, потому любите его горячо и будьте готовы душу свою за него положить...». 